\title{
Mild temperatures on bud breaking dormancy in peaches
}

\author{
Temperaturas amenas na superação da dormência de pessegueiros
}

\author{
Geraldo Chavarria' ${ }^{\mathrm{I}}$ Flávio Gilberto Herter ${ }^{\mathrm{II}}$ Maria do Carmo Bassols RaseiraII \\ Alexandre Couto Rodrigues ${ }^{\mathrm{II}}$ Carlos Reisser" João Baptista da Silva ${ }^{\mathrm{II}}$
}

\begin{abstract}
The search for low chill cultivars for peach production in areas with low chill accumulation (temperatures below $7.2^{\circ} \mathrm{C}$ ) has stimulated studies about the higher temperatures effects on low chill cultivars. The objective of this research was to evaluate the influence of mild temperatures on flowering and leafing of 'Turmalina' and 'Ágata' cultivars with low and medium low chilling requirements, respectively. Plants obtained by grafting flower twigs in the autumn, after the grafting, were submitted to chilling treatments $(150,250$, 350,500 and 672 hours) at three temperature levels $\left(5^{\circ} \mathrm{C}, 10^{\circ} \mathrm{C}\right.$ and $15^{\circ} \mathrm{C}$ ). After the end of the treatments, the plants had been taken to greenhouse $\left(20^{\circ} \mathrm{C} \pm 5^{\circ} \mathrm{C}\right)$ and evaluated weekly. The results showed that satisfactory flower and leaf development occur even at temperatures as high as $15^{\circ} \mathrm{C}$ for a period of 150 hours, in 'Turmalina' peach. Temperatures of $10^{\circ} \mathrm{C}$ for a period equal or superior to 350 hours promote satisfactory leafing in 'Ágata' peach. Temperatures of $10^{\circ} \mathrm{C}$ and $15^{\circ} \mathrm{C}$ cause earlier development of flowers and leaves in both cultivars when compared to $5^{\circ} \mathrm{C}$.
\end{abstract}

Key words: chilling requirement, dormancy, winter, budbreak.

\section{RESUMO}

A busca por cultivares pessegueiro com baixa necessidade em frio para regiões com pouco acúmulo de frio (temperaturas abaixo de $7,2^{\circ} \mathrm{C}$ ) tem estimulado estudos sobre o efeito de altas temperaturas sobre cultivares de baixa necessidade de frio. O objetivo desta pesquisa foi avaliar a influência de temperaturas amenas na floração e brotação da 'Turmalina' e 'Ágata', duas cultivares com baixa e média necessidade de frio, respectivamente. Plantas obtidas por enxertia no outono foram submetidas a tratamentos de frio (150, 250, 350, 500 e 672 horas) em três níveis de temperatura $\left(5^{\circ} \mathrm{C}, 10^{\circ} \mathrm{C}\right.$ e $\left.15^{\circ} \mathrm{C}\right)$. Após os tratamentos, estas plantas foram colocadas em casa de vegetação a temperatura de $20^{\circ} \mathrm{C} \pm 5^{\circ} \mathrm{C}$ e avaliadas semanalmente. Conclui-se que temperatura de até $15^{\circ} \mathrm{C}$ por um período de 150 horas é capaz de resultar em floração e brotação satisfatórias para a cultivar 'Turmalina'. Temperaturas de $10^{\circ} \mathrm{C}$ por um período igual ou superior a 350 horas promovem brotação satisfatória na cultivar 'Ágata'. Temperaturas de $10^{\circ} \mathrm{C}$ e $15^{\circ} \mathrm{C}$ comparadas a $5^{\circ} \mathrm{C}$ causam antecipação da floração e brotação e ambas cultivares.

Palavras-chave: necessidade de frio, dormência, inverno, brotação.

\section{INTRODUCTION}

Climatic changes have been affected the regularity of chilling hours during winter period and that affects the dormancy process of temperate fruits in South Brazil compromising yield and quality of production (CHAVARRIA, 2005). The dormancy period is a physiologic phenomenon characterized by absence of visible growth and reduced metabolic activity (SAMISH, 1954). LANG et al. (1987) divided this period in to paradormancy, endodormancy, and ecodormancy. Paradormancy refers to correlated inhibitions organ by organ; endodormancy occurs internally in the buds; and ecodormancy depends upon environment conditions.

Many aspects of the temperature influence on flower and leaf development have been widely studied such as in promoting dormancy breaking (EREZ

'Universidade de Passo Fundo (UPF), CP 611, 99001-970, Passo Fundo, RS, Brasil. E-mail: geraldochavarria@upf.br. Autor para correspodência.

"Embrapa Clima Temperado (CPACT), Pelotas, RS, Brasil.

"I'Universidade Federal de Pelotas (UFPel), Pelotas, RS, Brasil. 
\& LAVEE, 1971; PUTTI, 2001), causing floral necrosis $\left(>25^{\circ} \mathrm{C}\right)($ MONET \& BASTARD, 1971), depending of the level and duration of the plant's exposure (COUVILLON \& EREZ, 1985a) and breaking dormancy with warm temperatures in $\left(10-15^{\circ} \mathrm{C}\right)$ (CHAVARRIA \& RASEIRA, 2000).

Warm temperatures alternating with low temperatures can have a synergistic effect, promoting better or more rapid dormancy breaking compared to the effect of exclusively low temperatures for some cultivars EREZ \& COUVILLON (1987). The influence of temperature depends on the level, intensity, and stage of bud development (COUVILLON \& EREZ, 1985b). Results suggest differences in the level of dormancy for vegetative and floral buds among cultivars and within the same cultivar, depending on their location on the branches and their age (ZANETTE et al., 2000).

Some models consider that temperatures above $16^{\circ} \mathrm{C}$ negate the effect of chilling on the bud development, depending on the level exposure (RICHARDSON et al., 1974), however, other authors consider that high temperatures effects are dependent upon the level $\left({ }^{\circ} \mathrm{C}\right)$ of exposure (EREZ et al., 1990). There are temperatures capable of inhibiting or causing the break of the dormancy, by acting on endo- or ecodormancy (SUGIURA \& HONJO, 1997).

The physiological principles required for understanding how those features affect plants and their relationship in ecological aspects of adaptation are linked to topics of current concern such as global warming and need of increasing production of temperate fruit trees. The purpose of this work was to investigate the effects of warm temperature on flowering and leafing on two peach cultivars with different chilling requirements.

\section{MATERIAL AND METHODS}

The experiment was conducted at Embrapa Clima Temperado, Pelotas, Rio Grande do Sul, Brazil (31 $41^{\circ}$ 'S latitude, $52^{\circ} 21^{\prime} \mathrm{W}$ longitude and $60 \mathrm{~m}$ altitude), in the autumn and winter of 2004.

Productive branches of the peach cultivar 'Turmalina' (chilling requirement estimated in 200 chilling hours - $\mathrm{CH}$ at $7.2^{\circ} \mathrm{C}$, RASEIRA \& NAKASU, 1998) were grafted in May, whereas branches of 'Ágata' (chilling requirement estimated in $500 \mathrm{CH}$ at $7.2^{\circ} \mathrm{C}$, RASEIRA \& NAKASU, 1998) were grafted in June, following the methodology described by SILVEIRA et al. (2003). 'Capdeboscq' seedlings were used as rootstocks. Scions were not pruned, in order to avoid stimulating budbreak.
The grafts were planted in bags (five liters capacity) with a peat moss and sand potting mix (2:1 v:v). After 28 days under greenhouse conditions with a temperature range between $15^{\circ} \mathrm{C}$ and $21^{\circ} \mathrm{C}$, both cultivars were submitted to $5^{\circ} \mathrm{C}, 10^{\circ} \mathrm{C}$ and $15^{\circ} \mathrm{C} \pm 1^{\circ} \mathrm{C}$ temperatures, for $150,250,350$ and 500 hours in a growth chamber. However, in 'Ágata' was given a treatment of $672 \mathrm{~h}$ rather than $500 \mathrm{~h}$ because constant temperatures did not give the same results as field conditions in preliminary observations.

After cold treatments, the plants were taken to the greenhouse $\left(20 \pm 5^{\circ} \mathrm{C}\right)$, and evaluated weekly for percentage of flowers and leaves bud break. Phenological evaluations were also made weekly and buds at the floral phenological stage C1 (BRES et al., 1970) and vegetative buds at the green tip stage were counted. All the buds of each plant were counted when they were transferred to the greenhouse.

Two experiments (one for each cultivar) were conducted, constituting of a factorial $3 \times 4$, being temperatures (three levels) and chilling hours (four levels), totaling 12 treatments in five blocks, and four plants per plot. The percentage of flower and leaf buds that broke was transformed in $\operatorname{arc} \sin \sqrt{x / k}$, with $\mathrm{k}=100$. The data was submitted to variance analysis and the means compared by Tukey’s Test.

\section{RESULTS AND DISCUSSION}

In 'Turmalina', low chill cultivar, after 21 days of heat accumulation in the greenhouse, significant differences were observed among treatments in relation to the start of blooming and leafing. The highest percentages were obtained in plants submitted to treatments with 500 hours at $5^{\circ} \mathrm{C}$ and at $10^{\circ} \mathrm{C}$. However, at $15^{\circ} \mathrm{C}$ there were no differences among time exposure, except for the 150 hours chilling treatment, corresponding to the lowest percentage of flower buds opening (47.0\%) (Figure 1A).

Greater than $60 \%$ of flower buds broke dormancy in all the treatments independent of temperature in evaluation at 28 days, demonstrating that temperatures of $10^{\circ} \mathrm{C}$ and $15^{\circ} \mathrm{C}$ can promote flower development (Figure 1B).

The differences of chilling period and temperatures were significant; however, there was a highly significant interaction between the two factors (chilling hours $\mathrm{x}$ temperature). Therefore, the discussions are mainly about temperatures within chilling hours. Treatments with warm temperatures $\left(15^{\circ} \mathrm{C}\right)$ and longer time of exposure caused anticipation of blooming as compared to other treatments (Figure 1). Higher temperatures can induce the continuous 

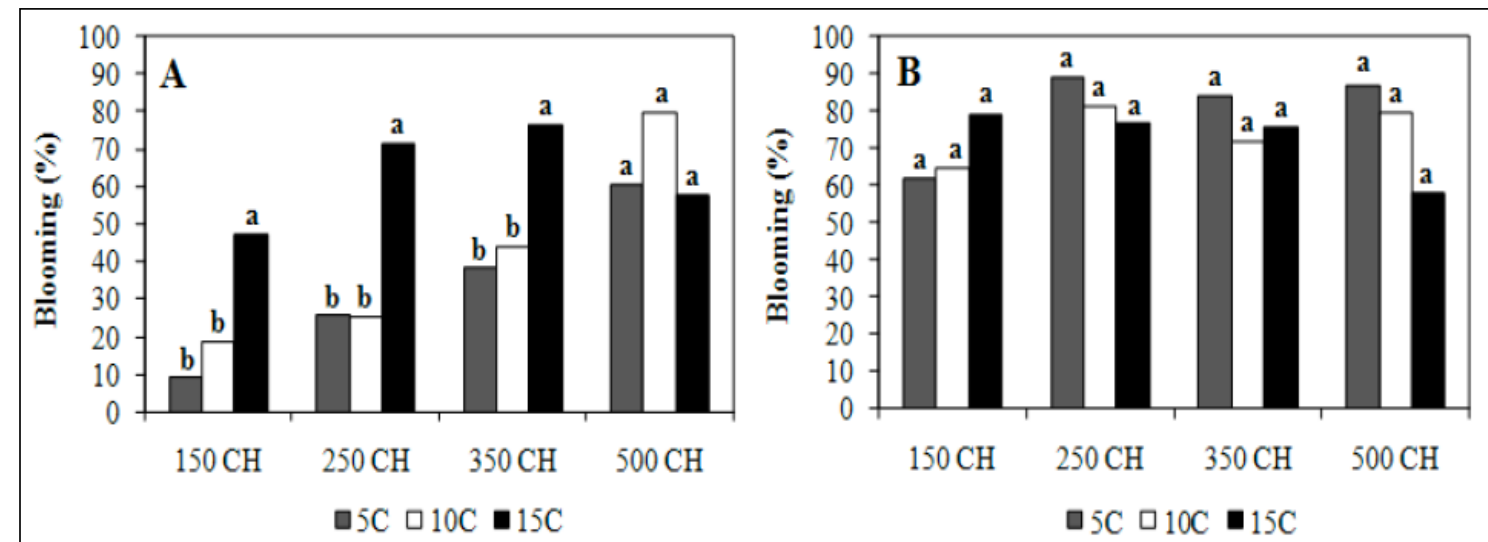

Figure 1 - Blooming percentage in low chill cultivar 'Turmalina' at two evaluations dates (21 (A) and 28 (B) days), after different chilling treatments $(\mathrm{CH})$. Pelotas. Brazil, 2004. Data in each chilling hours followed by the same letters do not differ in Tukey test, at $0.34 \%$ probability of error.

floral bud development altering the heat requirement. Differences among cultivars and among plants of the same cultivar but different treatments or locations, are due to the respiration process which may continue in high rates under warm conditions. Thus, when winter comes buds go dormant almost fully developed (CITADIN, 1999). In that manner cultivars with these characteristics have a low heat requirement as compared to cultivars with lower respiratory rates.

The longer exposure to chilling might have caused an advance in the beginning of bloom. These exposures to chilling temperatures might have triggered bud break (Figure 1). The flower buds have lower chilling requirements as compared to leaf buds. It was demonstrated that heat influences bud break in flower buds, and that winter chill reduces the buds heat requirement of these buds (CITADIN et al., 2001). Similar observations were obtained by SCALABRELLI \& COUVILLON (1986).

The metabolic rate of fruit trees growing in temperate climates decreases during the bud dormancy. However, in subtropical areas, warm temperatures causes continuous consuption of carbohydrates which are needed for budbreak in the spring season and which cause physiologic imbalances as a consequence. GARDIN (2002), reported flower abortion problems in pears, under mild winter conditions, explaining that the maintenance of high respiratory rates reduces starch accumulation and, that there is not enough solid soluble accumulation.

Another important factor in flower and leaf production is the effect of warm temperatures $\left(10^{\circ} \mathrm{C}\right.$ $15^{\circ} \mathrm{C}$ ) on deep dormancy. Some cultivars break dormancy very easily. This can be due to superficial dormancy or absence dormancy. Some peach cultivars can bloom and produce leaves without any chilling as long as they are under favorable environmental conditions $\left(21^{\circ} \mathrm{C}\right)$ achieving high budbreak percentages (CHAVARRIA, 2005).

Trees which keep their leaves until later in the fall may go into a deeper dormancy because leaves inhibit bud development (EDWARDS, 1985). The effect of temperature on dormancy, whether it is the effects of chilling on endodormancy or the effects of heat on ecodormancy, is very controversial. The precise beginning and ending of the endodormancy stage in temperate fruit trees is unknown, or at least, not agreed upon. Some authors reported dual effects of temperature in certain periods, in apple $\left(12^{\circ} \mathrm{C}\right)$ (ZANETTE, 1982) and pear $\left(9-10^{\circ} \mathrm{C}\right)$ (SUGIURA \& HONJO, 1997). According to RICHARDSON et al. (1975) temperate trees can accumulate heat at $4.5^{\circ} \mathrm{C}$.

It is important to emphasize that, in the present work, all plants were submitted to chilling treatments at the same time, to keep the bud development stages as uniform as possible, so that there was no influence on the temperature in distinct stages. However the plants were taken out of cold room at different times, according to the treatments.

Warm temperatures $\left(10^{\circ} \mathrm{C}\right.$ and $\left.15^{\circ} \mathrm{C}\right)$ had no negative effect on leafing of 'Turmanilna', promoting budbreak percentages greater than $62.5 \%$, except in plants submitted to 500 hours at $15^{\circ} \mathrm{C}$ (59\%). Evaluations done 21 days after chilling treatments showed differences only for plants exposed to $10^{\circ} \mathrm{C}$, for 500 hours (82.5\%). On the 28 days evaluations, the only significant difference observed was between treatments held for 500 hours at $10^{\circ} \mathrm{C}$ and $15^{\circ} \mathrm{C}$ (Figure 2).

The lowest values of leafing were obtained in plants receiving less than 500 hours of exposure to 


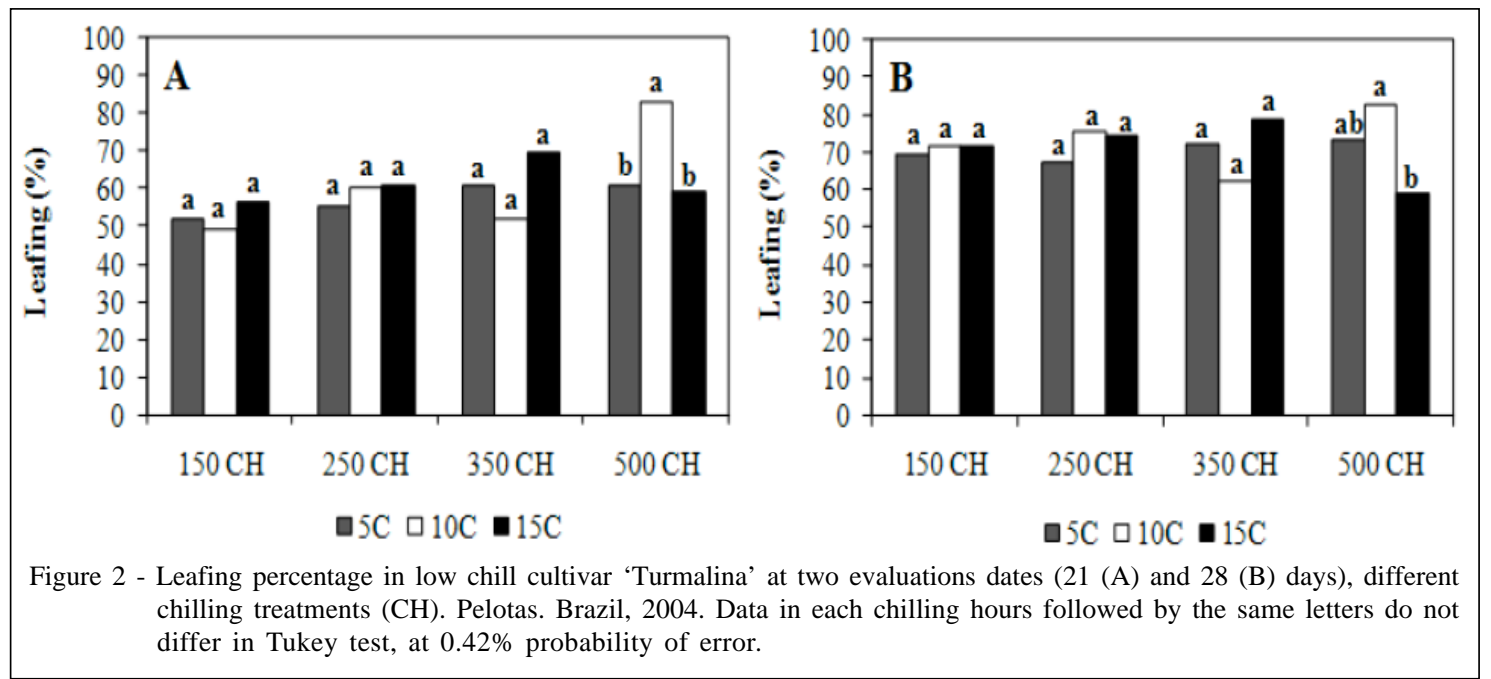

$15^{\circ} \mathrm{C}$, which can attribute to the paradormancy (Figure 2). Differences in dormancy level within buds of the same branch were already reported (VITI et al., 2003). The first buds that break dormancy can influence the ones close to them that are still dormant (BALANDIER, 1992). This could explain the low percentages of leaf budbreak through correlative inhibitions of the buds.

It is possibly that the treatments of $10^{\circ}$ and $15^{\circ} \mathrm{C}$ would not have the same effect on blooming and leafing, if plants had previously been submitted to cold in the orchard, before the branches were collected. This could interfere on the depth of the dormancy. The autumn chilling does not affect the dormancy breaking but the dormancy deepness (RAGEAU, 2002). Based on this hypothesis, warm temperatures would have affected dormancy breaking of cultivars like 'Turmalina', just in regions without chilling in autumn.

'Ágata', medium low chill cultivar, had lower percentages of blooming in all treatments; the best results were obtained with 672 hours of exposure to $5^{\circ} \mathrm{C}$ (36.3\%) (Figure 3). However, in leaf buds at the green tip stage were observed on several plants before the flower buds opened. This was particularly true with the $10^{\circ} \mathrm{C}$ and $15^{\circ} \mathrm{C}$ treatments. The possibility of necrosis due to high temperatures, in the greenhouse, was discarded (MONET \& BASTARD, 1971) because the plants previously at $5^{\circ} \mathrm{C}$ treatments opened the flowers, although in low percentages. However one explanation for the poor blooming is that it could have been caused by pathogen interference, probably fungal infection on the orchard. The effect would be worse for plants submitted to temperatures of $10^{\circ} \mathrm{C}$ and $15^{\circ} \mathrm{C}$ since they are more favorable for pathogens development than $5^{\circ} \mathrm{C}$. Unfortunately, in the present experiment, buds were not checked for pathogen incidence.

Observing the results obtained for 'Agata' it was possible to detect the direct relationship between percentage of leaf break and period of exposure for the three temperatures (Figure 4). The evaluations made at

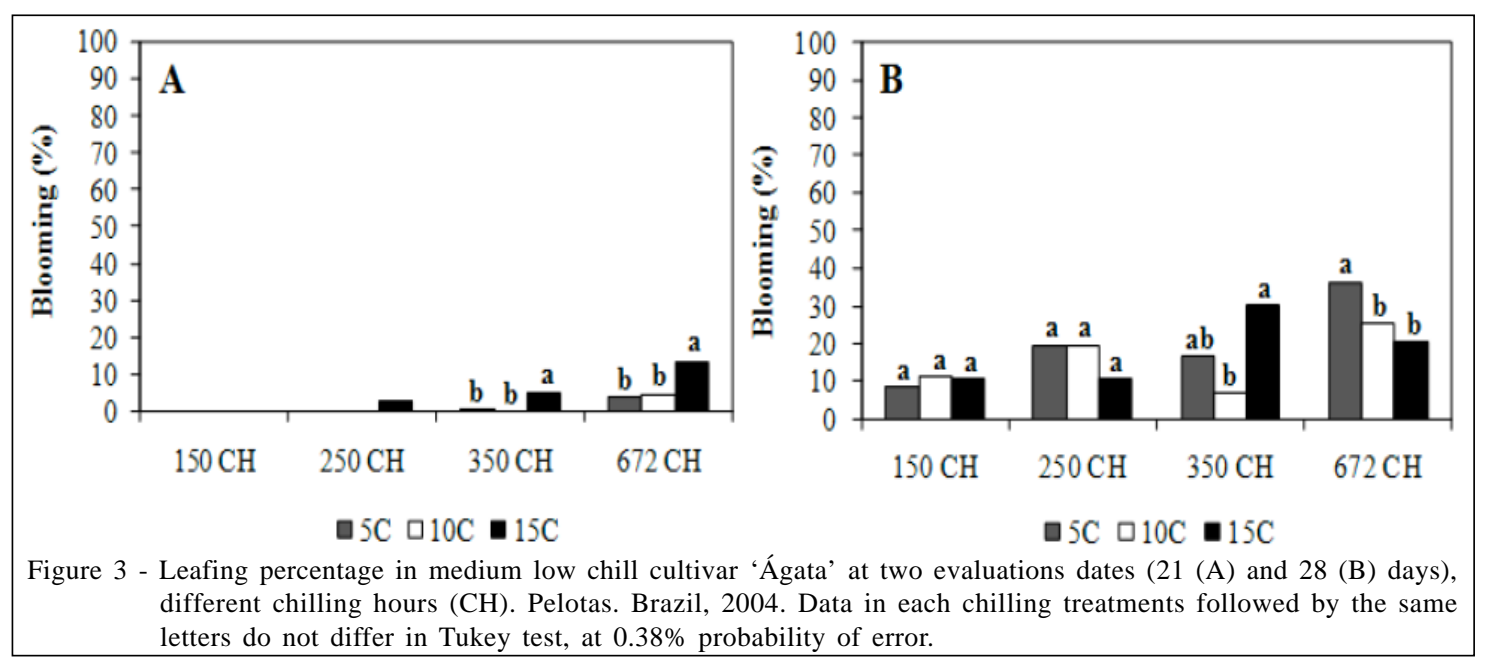

Ciência Rural, v.39, n.7, out, 2009. 


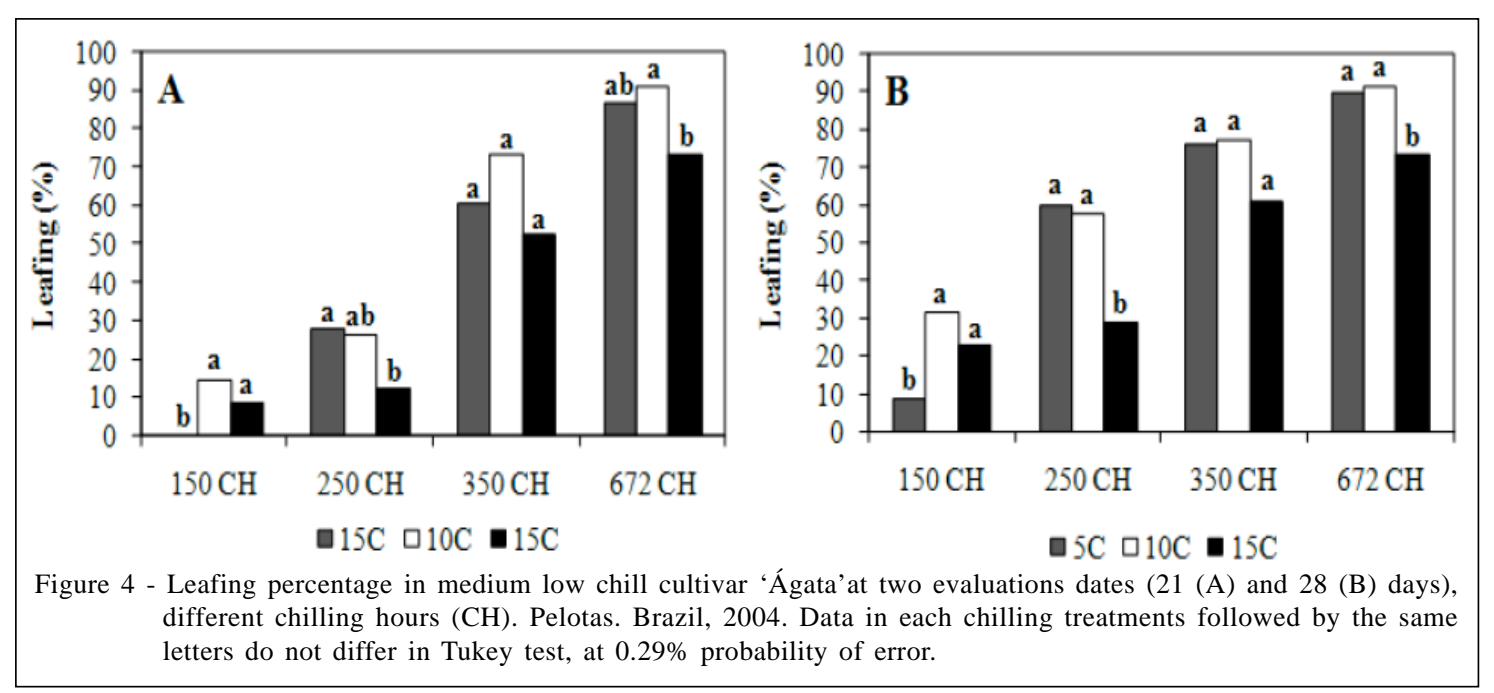

21 and 28 days did not show differences among $5^{\circ} \mathrm{C}$ and $10^{\circ} \mathrm{C}$ treatments at 672 hours of exposure, demonstrating the positive effect of warm temperatures $\left(10^{\circ} \mathrm{C}\right)$ even for higher chill cultivars. Comparing the two evaluations (21 and 28 days) in each chilling treatment, it could be observed that leaf budbreak was advanced at $10^{\circ} \mathrm{C}$ as compared to $5^{\circ} \mathrm{C}$ (Figure 4).

The lowest leafing percentages were observed on plants at $15^{\circ} \mathrm{C}$, although if time of exposure was 350 or 672 hours, the leaf break percentages achieved $60 \%$, which can be considered satisfactory. However, differences were observed in the plants at $15^{\circ} \mathrm{C}$ during 672 hours as compared to plants submitted at $5^{\circ} \mathrm{C}$, during the same period (Figure 4 ).

Regarding time of exposure, the 150 hour treatment resulted in the lowest leafing regardless of the temperature; however at $5^{\circ} \mathrm{C}$ budbreak was lower than other treatments. Perhaps, $5^{\circ} \mathrm{C}$ can serve as an inductor of deep dormancy in cv. 'Ágata'. Exposure for 150 hours at $15^{\circ} \mathrm{C}$ was enough to promote satisfactory percentages of budbreak (both flower and vegetative buds) in cv. 'Turmalina'. However, for cv. 'Ágata', it was necessary at least 350 hours and preferably at $10^{\circ} \mathrm{C}$ or $5^{\circ} \mathrm{C}$.

This study showed the need of further experiments relating temperature fluctuations and levels of dormancy to understand the turn on of the dormancy and to increase the knowledge of this process in warm regions.

\section{CONCLUSIONS}

Mild temperatures $\left(10\right.$ and $\left.15^{\circ} \mathrm{C}\right)$ promote flowering and leafing in 'Turmalina' peach and anticipation of theses phenological phases compared to $5^{\circ} \mathrm{C}$.

Temperatures of $5^{\circ} \mathrm{C}$ in the fall can be an inductor of deep dormancy in cv. 'Ágata'.

\section{REFERENCES}

BALANDIER, P. Étude dynamique de la croissance et du développement des bourgeons de quelques cultivars de pêcher cultivés à diverses altitudes sous le climat tropical de i'île de la Reunion. 1992. 82f. Thése (Doctorat Physiologie Végetale) - Université Blaise Pascal. Clermont Ferrand.

BRES, Y. et al. Recherches sur le développement du pêcher: Etude phénologique des boutons floraux. Phytoma - Defense de cultures, v.219, p.21-28, 1970.

CHAVARRIA, G. Efeito de temperaturas de $10^{\circ} \mathrm{C}$ e $15^{\circ} \mathrm{C}$ na floração e brotação de pessegueiro avaliado através de enxerto de ramos produtivos no outono. 2005. $56 \mathrm{f}$. Dissertação (Mestrado em Agronomia) - Faculdade de Agronomia Elisieu Maciel, Universidade Federal de Pelotas, Pelotas - RS

CHAVARRIA, G.; RASEIRA, M. do C. B. Chilling requirement in peach. In: PRUNUS BREEDERS MEETING, 2000, Pelotas. Summaries... Pelotas: Embrapa CPACT.2000. v.1, p.7880.

CITADIN, I. Necessidade de calor para antese e brotação em pessegueiro. [Prunus persica (L.) Batsch]. 1999. 74f. Dissertação (Mestrado em Agronomomia - Fruticultura de Clima Temperado) - Faculdade de Agronomia Eliseu Maciel, Universidade Federal de Pelotas, Pelotas - RS.

CITADIN, I. et al. Heat requirement for flower and leaf development in peach. Hortscience, v.36, n.2, p.305-307, 2001.

COUVILLON, G.A.; EREZ, A. Effect of level and duration of high temperatures on rest in the peach. Journal of the American Society for Horticultural Science, v.110, n.4, p.579-581, 1985a.

COUVILLON, G.A.; EREZ, A. Influence of prolonged exposure to chilling temperatures on bud break and heat requirement for bloom of several fruit species. Journal of the American Society for Horticultural Science, v.110, n.1, p.47-50, 1985b.

Ciência Rural, v.39, n.7, out, 2009. 
EDWARDS, G.R. Changes in endogenous hormones in apple during bud burst induced by defoliation. In: Tropical Horticulture X. Symposium, ISHS. Acta Horticulturae, v.158, p. 203210, 1985.

EREZ, A.; COUVILLON, G.A. Characterization of the influence of moderate temperatures on rest completion in peach. Journal of the American Society for Horticultural Science, v.112, n.4, p.677-680, 1987.

EREZ, A. et al. The dynamical model for rest completion in peach buds. Acta Horticulturae, v.276, p.165-174, 1990.

EREZ, A.; LAVEE S. The effect of climatic conditions on dormancy development of peach buds. Proceedings of the American Society for Horticultural Science, v.96, n.6, p.711-714, 1971.

GARDIN, J.P.P. Abortamento de gemas florais e níveis de carboidratos em gemas e ramos de pereira cultivar Nijisseiki no outono e inverno. 2002. 32f. Dissertação (Mestrado em Fisiologia Vegetal) - Universidade Federal de Pelotas, Pelotas - RS.

LANG, G.A. et al. Endo-, para- and ecodormancy: physiological terminology and classification for dormancy research. Hortscience, v.22, p.371-377, 1987.

MONET, R.; BASTARD, Y. Effects d'une température moderement éleveé: $25^{\circ} \mathrm{C}$, sur les bourgeons floraux du pêcher. Phisiologie Végétale, v.9, n.2, p.209-226, 1971.

PUTTI, G.L. Estudo das necessidades de frio e calor para a brotação de cultivares de macieira (Malus domestica, borck.). 2001. 61f. Dissertação (Mestrado em Agronomia Fruticultura de Clima Temperado) - Faculdade de Agronomia Eliseu Maciel, Universidade Federal de Pelotas, Pelotas -RS.

RAGEAU, R. Dormance des espèces fruitières de climat tempérée: nouveaux concepts. In: ENCONTRO NACIONAL SOBRE FRUTICULTURA DE CLIMA TEMPERADO, 5. 2002, Fraiburgo, SC. Anais... Caçador, SC: Epagri, 2002. $307 \mathrm{p}$.

RASEIRA, M. do C.B.; NAKASU, B.H. Cultivares: descrição e recomendação. In: MEDEIROS, C.A.B.; RASEIRA, M. do C.B. A cultura do pessegueiro. Brasília: Embrapa-SPI, 1998. p.29-97.
RICHARDSON E.A.; et al. A model for estimating the completion of rest for Redhaven and Elberta peach trees. Hortscience, v.9, p.331-332, 1974.

RICHARDSON E.A. et al. Pheno-climatografhy of spring peach bud development. Hortscience, v.10, p.236-237, 1975.

SAMISH, R.M. Dormancy in woody plants. Annales Physiologie Végetale, v.15, p.183-204, 1954.

SCALABRELLI, G.; COUVILLON, G.A. The effect of temperature and bud type on rest completion and the $\mathrm{GDH}^{\circ} \mathrm{C}$ requirement for budbreak in 'Redheaven' peach. Journal of the American Society for Horticultural Science, v.111, n.4, p.537-540, 1986.

SILVEIRA, C.A.P. et al. Ramos enxertados: uma nova alternativa para estudo da dormência de fruteiras de clima temperado. In: CONGRESSO NACIONAL DE HORTICUlTURA, 9., 2003. Montevideo. Anais... Salto, Uruguai: Sociedad Uruguya de Horticultura, 2003. p.62

SUGIURA T.; HONJO, H. A dynamic model for predicting the flowering date developed using an endodormancy break model and a flower bud development model in Japanese pear. Journal Agricultural Meteorological, v.54, n.5, p.897-900, 1997.

VITI, R. et al. The influence of sampling from different canopy positions on the evaluation of flower bud anomalies and dormancy in apricot (Prunus armeniaca L.). Fruits, v.58, p.117-126, 2003. Disponível em: $<\mathrm{ht} \mathrm{tp}: / / \mathrm{w}$ w w. fruits - journal.org/ index.php?option $=$ article\&access $=$ standard $\&$ Itemid $=129 \& u r l=/$ articles/fruits/pdf/2003/02/I3205.pdf $>$. Acesso em: 18 jun. 2009. doi: 10.1051/fruits:2002041.

ZANETTE, F. Efeito de algumas temperaturas de estocagem sobre a quebra de dormência das gemas e regeneração do sistema radical de porta-enxertos de macieira. Revista do Setor de Ciências Rurais, v.4, p.43-47, 1982.

ZANETTE, F. et al. Effect of low temperature on dormancy intensity in one, two and three year-old-buds of apple tree. In: INTERNATIONAL SYMPOSIUM ON PLANT DORMANCY, 2., 2000. Short communications... Angers: Université d'Angers, 2000. p.13-17. 